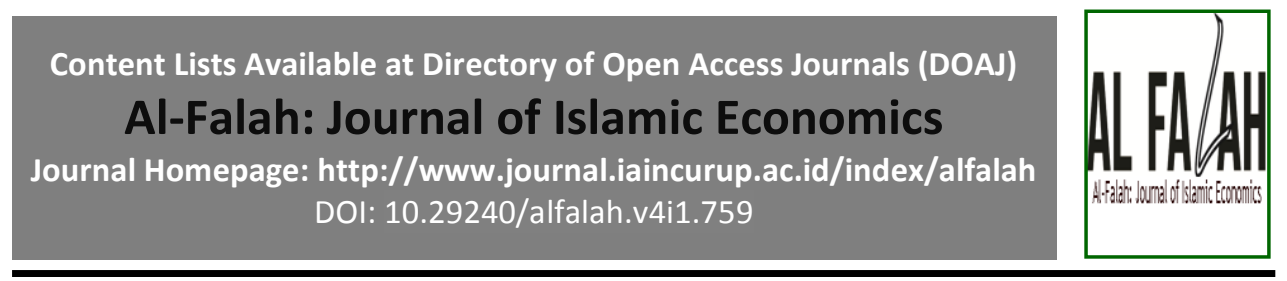

\title{
Integrasi Akad Pembiayaan dan Akad Rahn: Analisis Kritis terhadap Implementasi Fatwa DSN No. 92 Tahun 2014 pada PT. Pengadaian, Jakarta
}

\author{
Yupiter $^{a^{*}}$, Nurul Huda ${ }^{\mathrm{b}}$, Hendri Tanjung ${ }^{\mathrm{c}}$
}

abcPascasarjana Bisnis dan Manajemen Islam STEI Tazkia

*Email Address: yupiteryancik.yy@gmail.com

\begin{tabular}{c}
\hline ARTICLE INFO \\
\hline Article History: \\
Received \\
Revised \\
Accepted \\
\hline Keywords: \\
Akad \\
Fatwa \\
Rahn \\
Pembiayaan \\
Murabahah \\
\hline Paper Type: \\
Research Paper
\end{tabular}

\section{$\underline{\text { ABSTRACT }}$}

Purpose: The purpose of this article is to critically examine how the implementation of the MUI DSN Fatwa No. 92 of 2014 concerning financing accompanied bycontract rahn at PT. Procurement, Jakarta.

Design/Method/Approach : A qualitative approach is applied in this study, with design an exploratory research. The analysis unit is PT. Procurement, Jakarta. While the library research, and interviews are used as the main instruments in collecting relevant data.

Findings: In general, this study succeeded in identifying several important things, namely: First, that between DSN No. 92 of 2014 with the practices applied by PT. Procurement, Jakarta, is appropriate. Secondly, Islamic Pawnshop is relatively new as a financial system. This is one of the obstacles for PT. Procurement, Jakarta, in operating Islamic products.

Originality/Value: This research is believed to be important and significant in contributing to the theory. Especially, in terms of filling in the blanks of examplars of theories about the conformity of the DSN Fatwa No. 92 of 2014 with practice, especially at PT. Procurement, Jakarta.

\section{ABSTRAK}

Purpose: Tujuan artikel ini untuk mengkaji secara kritis bagaimana implementasi Fatwa DSN MUI No. 92 Tahun 2014 tentang pembiyaan disertai akad rahn pada PT. Pengadaian, Jakarta.

Design/Method/Approach :Pendekatan kualitatif diterapkan pada kajian ini, dengan design penelitian eksploratif. Adapun unit analisisnya adalah PT. Pengadaian, Jakarta. Sedangkan library research, dan wawancara dijadikan instrumen utama dalam mengumpulkan data yang relevan.

Findings: Secara umum penelitian ini berhasil mengidentifikasi beberapa hal penting, yakni: Pertama, bahwa antara DSN No. 92 Tahun 2014 dengan praktek yang diterapkan oleh PT. Pengadaian, Jakarta, sudah sesuai. Kedua, Pegadaian Syariah relatif baru sebagai suatu sistem keuangan. Ini menjadi salah satu hambatan bagi PT. Pengadaian, Jakarta, dalam mengoperasionalkan produk-produk syariah.

Originality/Value: Penelitian ini diyakini penting dan signikan dalam 


\section{PENDAHULUAN}

Manusia dalam memenuhi kebutuhan hidupnya sehari-hari, baik kebutuhan primer, sekunder maupun tersier tidak semuanya dapat terpenuhi, karena tidak memilki dana yang cukup, sehingga tidak jarang karena tidak ada barang yang dijual, ia terpaksa mencari pinjaman kepada orang lain.

Arus perkembangan dan kemajuan jaman membawa pengaruh signifikan terhadap kehidupan umat manusia. Pengaruh tersebut dapat terlihat hampir di segala bidang kehidupan. Mulai dari bidang sosial, politik, kebudayaan, teknologi, dan ekonomi. Salah satu bidang yang menjadi titik fokus dewasa ini adalah bidang ekonomi. Harus diakui, aspek ekonomi merupakan aspek kehidupan yang sangat dinamis. Artinya, selalu mengalami perubahan dan perkembangan dari waktu ke-waktu.

Perkembangan dunia perekonomian tersebut dipengaruhi oleh beberapa faktor, antara lain berkembangnya teknologi dan sistem informasi, munculnya jenis-jenis transaksi baru, tingkat intelektualitas masyarakat, dan lain sebagainya. Hal ini tentu membawa dampak yang sangat besar bagi sarana perkembangan dunia ekonomi. Islam sebagai agama yang komprehensif (rabmatan lil 'alamin), mengatur seluruh aspek kehidupan manusia sesuai yang telah disampaikan oleh Rasulullah SAW. Di dalam Islam, telah ditetapkan aturan-aturan dan hukumhukum, baik yang berlaku individual maupun sosial, atau lebih tepatnya, Islam mengatur seluruh tata kehidupan bermasyarakat. Salahsatu aspek yang diatur oleh Islam ialah aspek perekonomian.

Aspek perekonomian merupakan salah satu aspek terpenting bagi keberlangsungan hidup umat manusia. Dalam konsepsi Islam, hal ini tertuang ke dalam lima hal pokok dalam kehidupan manusia yang harus dijaga. Lima hal tersebut disebut lima kebutuhan primer, yakni menjaga agama (bifdr ad-din), menjaga jiwa (bifdz al-mal), menjaga akal (bifdz al-aqh), menjaga keturunan (bifdz an-nash) dan menjaga harta (hifdzal-mal). Penjagaan harta (hifdz al-mal) merupakan cerminan dari kegiatan ekonomi yang wajib hukumnya untuk dipatuhi dan diamalkan oleh setiap orang guna memenuhi kebutuhan hidup. Berbicara mengenai dunia perekonomian, satu hal yang tidak dapat disangkal ialah perihal sistem ekonomi. Terdapat dua sistem perekonomian yaitu sistem ekonomi konvensional dan sistem ekonomi syariah. Dan yang saat ini sedang mengalami tren positif ialah sistem ekonomi syariah.

Indonesia telah melaksanakan praktik perekonomian dengan menggunkakan prinsip syariah. Praktik tersebut dapat dijumpai di lembagalembaga keuangan, baik lembaga keuangan bank maupun non bank. Misalnya, bank syariah, asuransi syaraiah dan pegadaian syariah. Akad yang dijalankan 
terdiri dari akad yang bersifat tijarah maupun akad tabarru'Perkembangan kegiatan/ transaksi dengan sistem syariah tersebut tentunya diiringi oleh munculnya permasalahan-permasalahan baru. Permasalahan yang muncul lebih kompleks dan beragam. Salah satu permasalahn baru yang muncul dewasa ini adalah pembiayaan yang disertai rahn (al-tamwil al-mautsuq bil-rahn).

Pembiayaan adalah tugas pokok lembaga keuangan, termasuk lembaga keuangan syariah yang berupa pemberian dana kepada pihak-pihak yang membutuhkan. Pembiayaan sendiri terdiri dari beberapa jenis dan model. Seluruhnya menjadi pilihan bagi masyarakat ataupun pihak yang membutuhkan dalam menentukan model pembiayaan yang akan digunakan. Fenomena yang muncul di masyarakat akhir-akhir ini ialah terjadinya akad pembiayaan yang didalamnya disertakan rahn (gadai). Sebagai hal yang baru, tentunya model pembiayaan yang disertai rahn masih belum memiliki payung hukum secara syar'i. Untuk menjawab permasalahan tersebut, Majelis Ulama Indonesia, dalam hal ini Dewan Syariah Nasional mengeluarkan fatwa perihal pembiayaan yang disertai rabn (al-tamwil al-mautsuq bil-rabn).

Ditetapkannya fatwa tersebut pastilah berawal dari sebuah latar belakang dan alasan-alasan penting. Selain itu, proses ijtihad yang dilakukan oleh DSNMUI dalam menetapkan fatwa diatas juga menarik untuk dikaji. Berangkat dari hal tersebut, perlu kiranya dilakukan kajian analisis terhadap fatwa Dewan Syariah Nasional Majelis Ulama Indonesia (DSN-MUI) No. 92 Tahun 2014 tentang pembiayaan yang disertai rahn (al-tamwil al-mautsuq bil-rahn).( Wakidatul Ibtiar Habib: 2016)

Dengan berkembangnya perekonomian masyarakat yang semakin meningkat, maka seorang dapat mencari uang pinjaman melalui jasa pembiayaan baik melalui lembaga keuangan bank maupun lembaga keuangan non bank, diantaranya adalah Lembaga Pegadaian. Lembaga Pegadaian di Indonesia sudah lama berdiri sejak masa kolonial Belanda. Untuk menekan praktek pegadaian illegal serta memperkecil lintah darat yang sangat merugikan masyarakat, maka pemerintah kolonial Belanda memonopoli usaha pegadaian dengan mendirikan jawatan pegadaian yang berada dalam lingkungan Kantor Besar Keuangan. Kemudian pada tahun 1930 dengan stbl. 1930 nomor 226. jawatan pagadaian itu diubah bentuknya menjadi Perusahaan Negara berdasarkan pasal 2 IBWI (donesche Bedrijven Wet) yang berbunyi: penunjukan dari cabang-cabang dinas negara Indonesia sebagai perusahaan negara dalam pengertian undang-undang ini, dilakukan dengan ordonansi (Badrul Zaman, 1995: 153).

Penetapan fatwa No: 92/DSN-MUI/2014 tentang pembiayaan yang disertai rabn (al-tamwil al-mautsuq bil-rahn) dirasa sudah tepat, ditengah munculnya permasalahan-permasalahan seputar dunia perekonomian yang lebih kompleks. Fatwa tersebut memberikan kebolehan (halal) pada beberapa jenis akad pembiayaan untuk disertai rahn. Akad tersebut terdiri yakni: akad utang-piutang (al-dain), jual beli (al-ba`) yang tidak tunai, sewa-menyewa (ijarah) yang 
pembayaran ujrahnya tidak tunai, musyarakah (perkongsian), mudharabah, dan akad amanah (untuk menghindari penyelewengan perilaku).

Dari segi metode istinbath hukumnya, dalam menetapkan fatwa ini, Dewan Syariah Nasional (DSN) menggunakan metode maslahah mursalah. Hal ini terlihat pada segi maqashidnya, yakni bertujuan untuk berjaga-jaga atau menghindari adanya penyelewengan tindakan yang dilakukan pemegang amanah, yang akan membawa dampak tidak terpenuhinya tujuan akad/prestasi. Namun demikian, terdapat beberapa hal yang sekiranya masih perlu dilakukan kajian yang lebih mendalam. Hal tersebut terletak pada dibolehkannya rabn pada akad mudharabah. Padahal dalam akad mudharabah tidak disyaratkan adanya rahn (barang jaminan). Hal ini yang sekiranya perlu dikaji kembali demi sebuah kegiatan ekonomi yang bernialaikan kemaslahatan.

Peneliti memilih Kantor Pegadaian Syariah sebab PT. Pegadaian merupakan salah satu lembaga keuangan resmi di Indonesia yang bergerak dalam bidang penyaluran kredit masyarakat dengan menggunakan sistem gadai. Meskipun banyak perusahaan perbankan lainnya yang memiliki produk gadai, namun pada PT. Pegadaian transaksi gadai merupakan operasional utama perusahaan dan dapat dikatakan bahwa pada kantor Pegadaian Syariah transaksi pinjaman dengan sistem gadai paling banyak dilakukan.

Dengan mempertimbangkan kesamaan operasional pada seluruh kantor cabang Pegadaian Syariah di Indonesia, maka peneliti memilih kantor pusat "PT Pegadaian (Persero)" Jakarta sebagai obyek penelitian. Hal ini diperkuat dengan posisi peneliti yang dapat melakukan observasi partisipan pada obyek tersebut sehingga data yang peneliti dapatkan menjadi lebih optimal. Penelitian dilakukan pada kantor pusat "PT Pegadaian (Persero)" Jakarta untuk memahami pelaksanaan pembiayaan yang disertai rahn pada kantor pusat "PT Pegadaian (Persero)" Jakarta serta untuk mengetahui apakah implementasi pembiayaan yang disertai rahn Perusahaan kantor pusat "PT Pegadaian (Persero)" Jakarta telah sesuai dengan konsep pembiayaan rahn.

\section{LANDASAN TEORI}

\section{Akad Rahn}

Secara etimologi, kata ar-rahn berarti tetap, kekal, dan jaminan. Akad ar-rabn dalam istilah hukum positif disebut dengan barang jaminan, dan agunan. Dalam islam ar-rahn merupakan sarana tolong menolong bagi umat islam, tanpa ada imbalan jasa. ${ }^{1}$ Ada beberapa definisi ar-rahn yang dikemukakan ulama fiqh, ulama Malikiyah mendefinisikan bahwa harta yang dijadikan pemiliknya sebagai jaminan hutang yang bersifat mengikat. ${ }^{2}$ Menurut mereka, yang dijadikan barang jaminan (agunan) bukan saja harta yang bersifat materi, tetapi juga harta yang bersifat manfaat tertentu. Harta

\footnotetext{
${ }^{1}$ Nasrun Haroen, Fiqh Muamalah, 2 (Tangerang: Gaya Media Pratama, 2007), h. 251.

2 Dardir, Asy-Syarh Ash-Shagir Bi Syarh Ash-Shawi, vol. Vol. III (Mesir: Dar al-Ma'arif, tt), h. 303 .
} 
yang dijadikan jaminan tidak harus diserahkan secara aktual, tetapi boleh juga penyerahannya secara hukum, seperti menjadikan sawah menjadi jaminan, maka yang diserahkan itu adalah surat jaminannya (sertifikatnya). ${ }^{3}$ Ulama Hanafiyah mendefinisikan bahwa menjadikan suatu barang sebagai jaminan terhadap hak (piutang) yang mungkin dijadikan sebagai pembayar hak (piutang) itu, baik seluruhnya maupun sebagian. ${ }^{4}$ Sedangkan ulama Syafi'iyah dan Hanabilah mendefinisikan ar-rahn ${ }^{5}$ bahwa menjadikan barang sebagai jaminan hutang, yang dapat dijadikan pembayar hutang apabila orang yang berhutang tidak bisa membayar hutangnya itu.

Definisi yang dikemukakan Syafi'iyah dan Hanabilah ini mengandung pengertian bahwa barang yang boleh dijadikan hutang itu hanyalah harta yang bersifat materi; tidak masuk manfaat sebagaimana yang dikemukakan ulama Malikiyah, sekalipun manfaat itu, menurut mereka (Syafi'iyah dan Hanabilah), termasuk dalam pengertian harta. Ar-rahn ditangan al-murtabin (pemberi hutang) hanya berfungsi jaminan hutang ar-rabin (orang yang berhutang). Barang jaminan itu baru boleh dijual apabila dalam waktu yang disetujui kedua belah pihak. Sifat rabn secara umum dikategorikan sebagai akad yang bersifat derma, sebab apa yang diberikan penggadai (rabin) kepada penerima gadai (murtabin) tidak ditukar dengan sesuatu. Yang diberikan murtabin kepada rabin adalah utang, bukan penukar atas barang yang digadaikan. ${ }^{6}$

\section{Jual-beli}

Secara bahasa bai' berarti: menerima sesuatu dan memberikan sesuatu yang lain. Kata $b a i^{\prime}$ turunan dari kata "baa" yang berarti: depa. Hubungannya adalah kedua belah pihak (penjual dan pembeli) saling mengulurkan depanya untuk menerima dan memberikan. ${ }^{7}$ Secara istilah $b a i^{\prime}$ berarti: saling tukar-menukar harta dengan tujuan kepemilikan. Hukum asal bai' adalah mubah, namun terkadang hukumnya bisa berubah menjadi wajib, haram, sunat dan makruh tergantung situasi dan kondisi berdasarkan asas maslahat. ${ }^{8}$

\section{Akad Murabahah}

Sebagaimana diatur dalam Pasal 6 huruf (m) Undang-undang Nomor 10 Tahun 1998 tentang Perubahan atas Undang-undang Nomor 7 Tahun 1992 tentang Perbankan. bahwa salahsatu produk perbankan berdasarkan Prinsip Syariah

\footnotetext{
3 Vol. III: h. 303.

${ }^{4}$ Ibnu' Abidin, Radd Al-Mubtar 'ala Ad-Durr Al-Mukhtar, vol. Vol. IV (Beirut: Dar alFikr, tt), h. 339 .

${ }^{5}$ Asy-Syarbaini al Khatib, Mugni Al-Mubtaj (Beirut: Dar al-Fikr, 1978), h. 121. 2001), h. 160 .

${ }^{6}$ Muhammad Syafi'i Antonio, Bank Syariah Dari Teori Ke Praktek (Jakarta: Gema Insani,

7 Erwandi Tarmizi, "Gadai Emas Syariah, Kamuflase Riba," 2012, http://pro.pengusahamuslim.com/read/-gadai-emas-syariah-kamuflase-riba-.

${ }^{8}$ Eni Endari, "Meraih Keunggulan Melalui Pengintegrasian Perencanaan Sumber Daya Manusia Dan Perencanaan Strategik," Jurnal Siasat Bisnis 0 (January 1, 2005): h. 240, https://doi.org/10.20885/JSB.ed.khus.art3.
} 
adalah Perjanjian Murabahah. Perjanjian atau pembiayaan murabahab juga menjadi produk yang ditawarkan Pegadaian Syariah.

Murabahah menurut Sutan Remi Sjahdeni Murababah adalah jasa pembiayaan dengan mengambil bentuk transaksi jual beli dengan cicilan. Pada perjanjian Murabahah atau mark up, bank membiayai pembelian barang atau asset yang dibutuhkan oleh nasabahnya dengan membeli barang itu dari pemasok barang dan kemudian menjualnya kepada nasabah tersebut dengan menambahkan suatu mark up/keuntungan. ${ }^{9}$ Menurut Dewan Syariah Nasional Murabahah adalah menjual suatu barang dengan menegaskan harga belinya kepada pembeli dan pembeli membayarnya dengan harga yang lebih sebagai laba. ${ }^{10}$ Perjanjian murababah adalah jasa pembiayaan dengan mengambil bentuk transaksi jual beli dengan angsuran. Pada perjanjian murababah pegadaian syariah membiayai pembelian barang atau asset yang dibutuhkan oleh nasabahnya dengan membeli barang itu dari pemasok barang dan kemudian menjualnya kepada nasabah tersebut dengan menambahkan suatu keuntungan. Dengan kata lain, penjualan barang olrh pegadaian syariah kepada nasabah dilakukan atas dasar cost plus profit. ${ }^{11}$ Pembayaran dari nasabah dilakukan dengan cara angsuran dalam jangka waktu yang telah ditentukan. Sistem pembayaran secara angsuran tadi dikenal dengan istilah Bai' Bitsaman Ajil. ${ }^{12}$ Baik mengenai barang yang di butuhkan oleh nasabah maupun tambahan biaya yang akan menjadi imbalan bagi Pegadaian Syariah, dirundingkan dan ditentukan dimuka oleh pegadaian syariah dan nasabah yang bersangkutan. Dalam jual beli murabahah ini kejujuran penjual sangat penting sebagaimana tersebut dalam QS. Al-Anfal (8) ayat 27 yang berbunyi sebagai berikut:

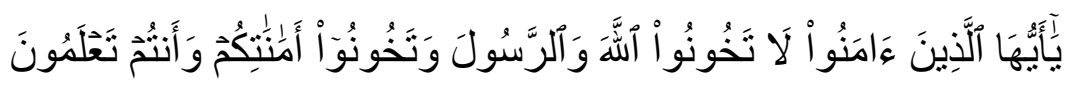

Artinya: "Hai orang-orang yang beriman, janganlah kamu mengkbianati Allah dan Rasul (Mubammad) dan (juga) janganlah kamu mengkbianati amanatamanat yang sedang dipercayakan kepadamu, sedang kamu mengetabui".

Produk Pegadaian Syariah

Produk dan layanan jasa yang ditawarkan oleh Pegadaian Syariah kepada masyarakat berupa: Pertama, Pemberian pinjaman atau pembiayaan atas dasar hukum gadai syariah. Produk ini mensyaratkan pemberian pinjaman dengan penyerahan barang sebagai jaminan. Barang gadai harus berbentuk barang bergerak, oleh karena itu pemberian pinjaman sangat ditentukan oleh nilai dan jumlah dari barang yang digadaikan. Kedua, Jasa Taksiran. Di samping memberikan pinjaman kepada masyarakat, pegadaian syariah juga memberikan

\footnotetext{
9 Sjahdeni Sutan Remi, Perbankan Islam Dan Kedudukannya Dalam Tata Hukum Perbankan Indonesia (Jakarta: Pustaka Utama Graffiti, 2005), h. 64.

${ }^{10}$ Wiroso, Jual Beli Murabahah (Yokyakarta: UII Press, 2005), h. 14.

${ }^{11}$ Perbankan Islam Dan Kedudukannya Dalam Tata Hukum Perbankan Indonesia, h. 65.

12 Arifin Zainal, Memahami Bank Syariah (Jakarta: Alvabet, 2000), h. 116.
} 
pelayanan berupa jasa penaksiran atas nilai suatu barang. Jasa yang ditaksir biasanya meliputi semua barang bergerak dan tidak bergerak. Jasa ini diberikan kepada mereka yang ingin mengetahui kualitas barang seperti emas, perak, dan berlian. Biaya yang dikenakan pada nasabah adalah berupa ongkos penaksiran barang.

Ketiga, Jasa Titipan (ijarah). Pegadaian syariah juga menerima titipan barang dari masyarakat berupa surat-surat berharga seperti sertifikat tanah, ijazah, motor. Fasilitas ini diberikan bagi mereka yang ingin melakukan perjalanan jauh dalam waktu yang relatif lama atau karena penyimpan di rumah dirasakan kurang nyaman. Atas jasa penitipan tersebut, gadai syariah memperoleh penerimaan dari pemilik barang berupa ongkos penitipan. Keempat, Penjualan logam mulia, yaitu jasa penyediaan fasilitas berupa tempat penjualan emas eksekutif yang terjamin kualitas dan keasliannya. Gold counter ini semacam toko dengan emas galeri 24, di mana setiap pembelian emas di toko milik Pegadaian Syariah akan dilampiri sertifikat jaminan. Hal ini dilakukan untuk memberikan pelayanan bagi masyarakat kelas menengah, yang masih peduli dengan image. Dengan sertifikat tersebut masyarakat percaya dan yakin akan kualitas dan keaslian emas.

\section{METODE PENELITIAN}

Penelitian ini menggunakan jenis penelitian kualitatif dengan pendekatan eksploratory guna mengetahui pembiayaan yang disertai dengan rabn pada pegadaian syariah dengan sistem syariah di kantor pusat PT Pegadaian (Persero) Jakarta (Huda, 2016: 137). Penelitian eksploratory adalah penelitian yang bertujuan menggali/mencari variabel-variabel atau faktor-faktor yang terdapat pada suatu fenomena/kondisi/setting sosial tertentu dan eksplorasi dari sesuatu yang belum diketahui atau belum banyak informasi yang tersedia tentang hal atau tempat atau situasi tertentu. ${ }^{13}$

Pada penelitian ini peneliti ingin menganalisis Pelaksanaan Fatwa 92/2014 "pembiayaan yang disertai dengan rahn" pada pegadaian syariah dengan sistem syariah di kantor pusat PT Pegadaian (Persero) Jakarta. Dengan metode kualitatif peneliti ingin menganalisis permasalahan secara mendalam mengenai pada tiga permasalahan : Bagaimana pelaksanaan Fatwa 92/2014 "pembiayaan yang disertai dengan rahn" pada pegadaian syariah dengan sistem syariah di kantor pusat PT Pegadaian (Persero) Jakarta?, dan Apakah hambatan pelaksanaan Fatwa 92/2014 "pembiayaan yang disertai dengan rahn" pada PT Pegadaian (Persero) Jakarta ?. Dalam melakukan penelitian dan pembahasan masalah, penulis menggunakan teori tentang implementasi hukum, prinsipprinsip syari'ah dalam lembaga keuangan, teori pelaksanaan pembiayaan yang disertai dengan rahn serta teori pengembangan sistem operasional pegadaian

13 Kumar, Research Methodology: Step by Step Guide for Beginners, II (London: Sage Publication Ltd, 2005), h. 1. 
syari'ah. Kemudian yang terakhir adalah sumber data yang merupakan penerima pelayanan yaitu masyarakat. Pengamatan juga sangat perlu dilakukan agar dapat dijadikan suatu pembanding dengan hasil wawancara. Setelah melakukan penelitian diharapkan diperoleh suatu kesimpulan umum.

\section{TEMUAN DAN PEMBAHASAN}

Implementasi DSN No. 92/2014 Pada Pegadaian Syariab

Dalam Unit Pegadaian Syariah akad sangat diperhatikan, akad merupakan suatu alat transaksi yang digunakan sebagai pertemuan ijab dan kabul dalam proses gadai. Di Pegadaian Syariah tedapat dua akad yang menjadi alat dalam melakukan gadai, yaitu akad jjarah dan akad rahn. Berdasarkan hasil wawancara dengan Irfan Syauqi Beik selaku Dewan Syariah Nasioanal (DSN) menyatakan sebagai berikut:

"Ya tentu dalam praktiknya akad rabn ini tidak berdiri sendiri, ia diikuti dengan akad qordh, ijarah, sehingga boleh dikatakan ada praktiknya disebut dengan rabn itu tidak murni rahn, tapi akad yang sifatnya multi pada praktiknya dan kerena pegadaian ini diawasi oleh lembaga keuangan dan menjadi salah satu komponen yang diawasi karena ada direktoratnya IKMB syariab OJK. Kalau dari sisi praktek, tentu setiap lembaga keuangan yang terdaftar dan diawasi oleh OJK mendapatkan pengawasan oleb OJK dan pada prakriknya saya melihat memang walaupun mingkin saja sebenarnya DPS yang mestinya bisa menyampaikan dan bisa jadi ada pelanggaran-pelanggaran, tetapi secara umum tentu semua lembaga keuangan syariah termasuk pegadaian, dia harus menyesuaikan praktiknya dengan ketentuan fatwa DSN MUI dan juga dengan peraturan OJK. Saya melibat secara umum pegadaian syariah ini praktinya sudah mengikuti pada ketentuan DSN dan juga fatwa ketentuan OJK semua, termasuk Perbankan dan sebagainya. Kira-kira begitu walaupun sekali lagi tadi rabn ini tidak berdiri sendiri tidak murni rahn dia, melainkan ada multi akad, Ada beberapa akad di dalamnya dan itu dipandang sebagai satu kesatuan". ${ }^{14}$

Dari penjelasan di atas, dapat disimpulkan bahwa akad rahn ini tidak berdiri sendiri, Pegadaian Syariah ini diawasi oleh beberapa lembaga keuangan dan diawasi oleh Otoritas Jasa Keuangan (OJK), pada praktiknya mungkin saja sebenarnya Dewan Pengawas Syariah (DPS) yang mestinya bisa mengawasi secara umum tentu semua lembaga keuangan syariah termasuk Pegadaian Syariah dia harus menyesuaikan praktiknya dengan ketentuan Fatwa DSN MUI dan juga dengan peraturan OJK, jadi peneliti melihat kalau dari penjelasan di atas, secara umum Pegadaian Syariah ini praktinya sudah mengikuti pada ketentuan DSN dan juga Fatwa DSN MUI, sekali lagi rahn ini tidak berdiri

14 Wawancara dilakukan pada hari Kamis tanggal 6 Juli 2017 
sendiri tidak murni rahn, dia ada multi akad ada beberapa akad di dalamnya dan itu dipandang sebagai satu kesatuan. Adapun menurut peneliti Pembiayaan merupakan salah satu tugas pokok bank, yaitu pemberian fasilitas penyediaan dana untuk memenuhi kebutuhan pihak-pihak yang merupakan defisit unit. Menurut sifat penggunaannya, pembiayaan dapat dibagi dua hal yaitu pembiayaan produktif dan konsumtif.

Pembiayaan produktif, yaitu pembiayaan yang ditujukan untuk memenuhi kebutuhan produksi dalam arti luas, yaitu untuk peningkatan usaha, baik usaha produksi, perdagangan, maupun investasi. Sedangkan pembiayaan konsumtif, yaitu pembiayaan yang digunakan untuk memenuhi kebutuhan konsumsi, yang akan habis digunakan untuk memenuhi kebutuhan. Lembagalembaga keuangan syariah saat ini telah memberikan pelayanan secara optimal, meskipun masih banyak aspek yang harus diperbaiki. Namun terlepas dari itu semua, lembaga keuangan syariah menyediakan beberapa jenis akad yang dapat diakses oleh nasabah dan masyarakat luas. Akad-akad tersebut antara lain bai' murabahah, salam, mudharabah, mu₹araah, musyarakah, qardh, hawalah, wakalah, dan rahn. Adapun akad ijarah tidak terpisahkan dengan akad rahn, di mana akad rahn merupakan serah terima marbun atau barang antara rabin dan murtabin dan diterimanya marbun bib oleh rabin, sedangkan ijarah terjadi setelah akad rabin, serta rahin di dalam akad ijarah tersebut dinyatakan sanggup dan setuju untuk membayar ijarah sewa dari marbun bih yang harus ditanggung oleh rabin akibat dari akad rabin.

Penepatan biayah ijarah pada transaksi rahn di Unit Pegadaian Syariah secara garis besar sudah sesuai dengan Fatwa MUI. Biaya ijarah yang dikenakan pada nasabah dihitung 10 hari. Nasabah akan diberi surat yang berisikan besarnya tarif ijarah yang harus dibayar sesuai tanggal pelunasan yang dilakukan oleh rahn. Namun demikian, ada ketidaksesuaian antara Fatwa MUI dengan praktik yang terjadi di lapangan. Berdasarkan Fatwa Dewan Syariah Nasional Majelis Ulama Indonesia No: 25/DSN-MUI/III/2002 tentang rahn ayat 4 menyebutkan bahwa besar biaya pemeliharaan dan penyimpanan marbun tidak boleh ditentukan berdasarkan jumlah pinjaman melainkan dengan nilai taksiran, namun yang terjadi pada Unit Pegadaian Syariah dalam penentuan tarif biaya ijarah berdasarkan dengan penggolongan marbun bib dengan adanya pemberian diskon ijarah, dimana biaya ijarah akan berbeda jika pinjaman di bawah maksimum meskipun degan taksiran yang sama. Apabila nasabah menggadaikan barang dengan taksiran yang sama tetapi melukan pinjaman maksimum, maka nasabah tidak mendapatkan diskon ijarah. Pemberian diskon ini didasarkan pada pertimbangan bahwa nasbah yang tidak melakukan pinjaman maksimum akan mengurangi resiko yang dihadapi oleh Unit Pegadaian Syariah sehingga nasabah tidak perlu membayar penuh serta memberi keringanan ijarah pada nasabah.

Semisal ada dua nasbah yang menggadaikan satu jenis barang yang sama, dan nilai taksiran sama, nasabah pertama melakukan pinjaman maksimim dari nilai taksiran pinjaman maksimum, nasabah kedua meminjam di bawah 
maksimum dari nilai taksiran pinjaman maksimum. Pihak Unit Pegadaian Syariah memberlakukan antara nasabah pertama dan nasbah kedua secara berbeda, untuk nasabah pertama tidak diberikan diskon biaya ijarah. Untuk nasabah kedua diberi diskon ijarah.

\section{Operasional Pegadaian Syariah}

Implementasi operasi Pegadaian Syariah hampir mirip dengan pegadaian konvensional. Tidak berbeda dengan pegadaian konvensional, Pegadaian Syariah juga menyalurkan uang pinjaman dengan jaminan barang bergerak. Prosedur untuk memperoleh kredit gadai syariah sangat sederhana, nasbah hanya menunjukkan bukti identitas diri dan barang bergerak sebagai jaminan, uang pinjaman dapat diperoleh dalam waktu yang tidak relatif lama, nasabah cukup dengan menyerahkan sejumlah uang dan surat bukti rahn saja dengan waktu proses yang sangat singkat. Menurut pandangan dari hasil wawancara dengan Rully Yusuf selaku General Manager SBU Syariah PT Pegadaian (Persero) Jakarta menyatakan sebagai berikut:

\section{"Pegadaian Syariah dalam menjalankan operasionalnya berpegang kepada prinsip syariah. Pada dasarnya, produk-produk berbasis syariah memiliki karakteristik, seperti tidak memungut bunga dalam berbagai bentuk karena riba, menetapkan uang sebagai alat tukar bukan sebagai komoditas yang diperdagangkan, dan melakukan bisnis untuk memperoleb imbalan atas jaza dan/atau bagi hasil."15}

Dari penjelasan di atas peneliti dapat menyimpulkan bahwa Pegadaian Syariah akan selalu berpegang teguh kepada prinsip syariah, baik dari produkproduknya yang ditawarkan kepada para nasabah, maupun berupa pelayanpelayanan yang terbaik, dan Pegadaian Syariah berusaha sejauh mungkin untuk menghindari pelayanan bertransaksi yang mengandur unsur riba. Adapun menurut peneliti. Mekanisme operasi pegadaian syariah hampir sama dengan pegadaian konvensional. Seperti halnya pegadaian konvensional, pegadaian syariah juga menyalurkan uang pinjaman dengan jaminan barang bergerak.

Untuk memperoleh kredit gadai syariah sangat sederhana, masyarakat hanya menunjukkan bukti identitas diri dan barang bergerak sebagai jaminan, uang pinjaman dapat diperoleh dalam waktu yang tidak relatif lama (kurang lebih 15 menit saja). Begitupun untuk melunasi pinjaman, nasabah cukup dengan menyerahkan sejumlah uang dan surat bukti rahn saja dengan waktu proses yang juga singkat. Operasional pegadaian syariah menggambarkan hubungan di antara nasabah dan pegadaian. Menurut pandangan dari hasil wawancara dengan Risma Ekawati selaku Nasabah PT Pegadaian (Persero) Jakarta menyatakan sebagai berikut:

15 Wawancara dilakukan pada hari Jum'at tanggal 26 Mei 2017 
"Tentang pelayanan pengalaman saya bertransaksi di Pegadaian Syariah relatif nyaman dan cepat. Pegadaian Syariah memberikan pelayanan yang terbaik mengenai pengetabuan pembiayaan di Pegadaian Syariah. Adapun produk-produk. yang ditawarkan berbasis syariah memiliki karakteristik, seperti tidak. memungut bunga dalam berbagai bentuk. karena riba,". ${ }^{16}$

Dari penjelasan di atas dapat disimpulkan bahwa nasabah sangat puas dengan pelayanan yang diterima ketika bertransaksi di Pegadaian Syariah. Mereka sangat terkesan, apalagi ketika nasabah belum mengerti akad dan anturan bertransaksi, pihak karyawan dan petugas lansung menjelaskan sampai para nasabah mengerti dan paham akad Pegadaian Syariah dan ini yang kita harapkan, semoga pelayanan, seperti selalu ditingkatkan agar perkembangan usaha di Pegadaian Syariah signipikan setiap tahunnya.

Menurut peneliti layanan ini juga bisa dirasakan manfaatnya bagi masyarakat menengah bawah dengan tingkat moral hazard yang juga tidak besar. Pun jika ada persoalan dalam pengembalian dana pembiayaan oleh nasabah, pegadaian bisa melelang barang gadai untuk melunasi dana pembiayaan dan ujrah. Kalau ada persoalan nasabah dan lembaga bisa diselesaikan dengan proses itu karena barang gadai disimpan lembaga.

\section{Model Transaksi}

Sesuai dengan landasan konsep di atas, pada dasarnya Pegadaian Syariah berjalan di atas akad transaksi Syariah yaitu ${ }^{17}$ : Pertama, Akad Rabn, yaitu menahan harta milik si peminjam sebagai jaminan atas pinjaman yang diterimanya, pihak yang menahan memperoleh jaminan untuk mengambil kembali seluruh atau sebagian piutangnya. Dengan akad ini pegadaian menahan barang bergerak sebagai jaminan atas utang nasabah. Kedua, Akad Ijarah, yaitu akad pemindahan hak guna atas barang dan atau jasa melalui pembayaran upah sewa, tanpa diikuti dengan pemindahan kepemilikan atas barangnya sendiri. Melalui akad ini dimungkinkan bagi pegadaian untuk menarik sewa atas penyimpanan barang bergerak milik nasbah yang telah melakukan akad. Menurut pandangan dari hasil wawancara dengan Rully Yusuf. Selaku General Manager SBU Syariah PT Pegadaian (Persero) Jakarta, menyatakan sebagai berikut:

"Pada saat ini, perbitungan biaya ijarah oleh pibak unit pegadaian syariah dibitung per 10 hari, dalam jangka waktu kredit 120 bari atau 4 bulan. Apabila sudah sampai jatuh tempo nasabah belum bisa melunasi pinjaman, maka nasabah bisa melakukan perpanjangan atau cicilan. Dalam melakukan perpanjangan atas pembiayaan rahn, nasabah wajib membayar ijarah dan biaya administrasi tanpa harus melunasi uang pinjaman atau marbun bib. Kemudian dalam penentuan biaya

16 Wawancara dilakukan pada hari Ahad tanggal 11 Juni 2017

${ }^{17}$ Isi Akad Rahn Nomor ML100018/MULIA/03/2010 tanggal 19 Maret 2010. 
ijarah, kami selaku pihak pegadaian syariah PT. Pegadaian (persero) Jakarta ditentukan oleh nilai harga taksiran, dan apabila melakukan pinjaman di bawah maksimum dari nilai taksiran pinjaman, maka akan diberikan diskon ijarah. Adapun persentase taksiran yang diterapkan oleh kami selaku pibak PT. Pegadaian (persero) Jakarta berdasarkan buku panduan pegadaian syariah yang telah ditentukean ${ }^{\text {"18 }}$

Dari penjelasan di atas dapat disimpulkan bahwa perhitungan biaya ijarah yang di terapkan oleh pihak PT Pegadaian (Persero) Jakarta berdasarkan dengan taksiran barang dan apabila pinjaman dibawah maksimum akan diberikan diskon ijarah, biaya ijarah yang dikenakan kepada nasabah dihitung per 10 hari dalam batas waktu maksimal 120 hari. Menurut peneliti. Konsep gadai syariah diterapkan akad jjarah yang merupakan akad pemindahan manfaat atas suatu barang atau jasa dalam jangka waktu tertentu melalui pembayaran upah/sewa tempat, tanpa diikuti pemindahan kepemilikan barang itu sendiri. Dan sebagaimana dalam pembahasan diatas, penerapan akad ijarah terdapat kebolehan untuk menggunakan manfaat atau jasa sesuai dengan perizinan kedua belah pihak yang bersangkutan dengan suatu penggantian yang berupa fee atau kompensasi.

Adapun akad Qardh (Lihat: langkah 1), yaitu akad pinjaman kepada nasabah dengan ketentuan dana tersebut wajib dikembalikan kepada lembaga keuangan syariah. Pinjaman tersebut bisa digunakan untuk tujuan komersial maupun sosial. Sebagai penerima gadai atau disebut murtabin, penggadai akan mendapatkan Surat Bukti Rahn (SBR) berikut dengan akad pinjam-meminjam yang disebut Akad Gadai Syariah dan Akan Sewa Tempat (Ijarah). Dalam akad gadai syariah disebutkan bila jangka waktu akad tidak diperpanjang, maka penggadai menyetujui agunan (arbun) miliknya dijual oleh murtabin guna melunasi pinjaman. Adapun akad sewa tempat (Ijarah) merupakan kesepakatan antara penggadai dengan penerima gadai untuk menyewa tempat untuk penyimpanan dan penerima gadai akan mengenakan jasa simpan.

18 Wawancara dilakukan pada hari Jum'at tanggal 26 Mei 2017 


\section{Diagram 1.}

Skema Akad Rahn dan Ijarah

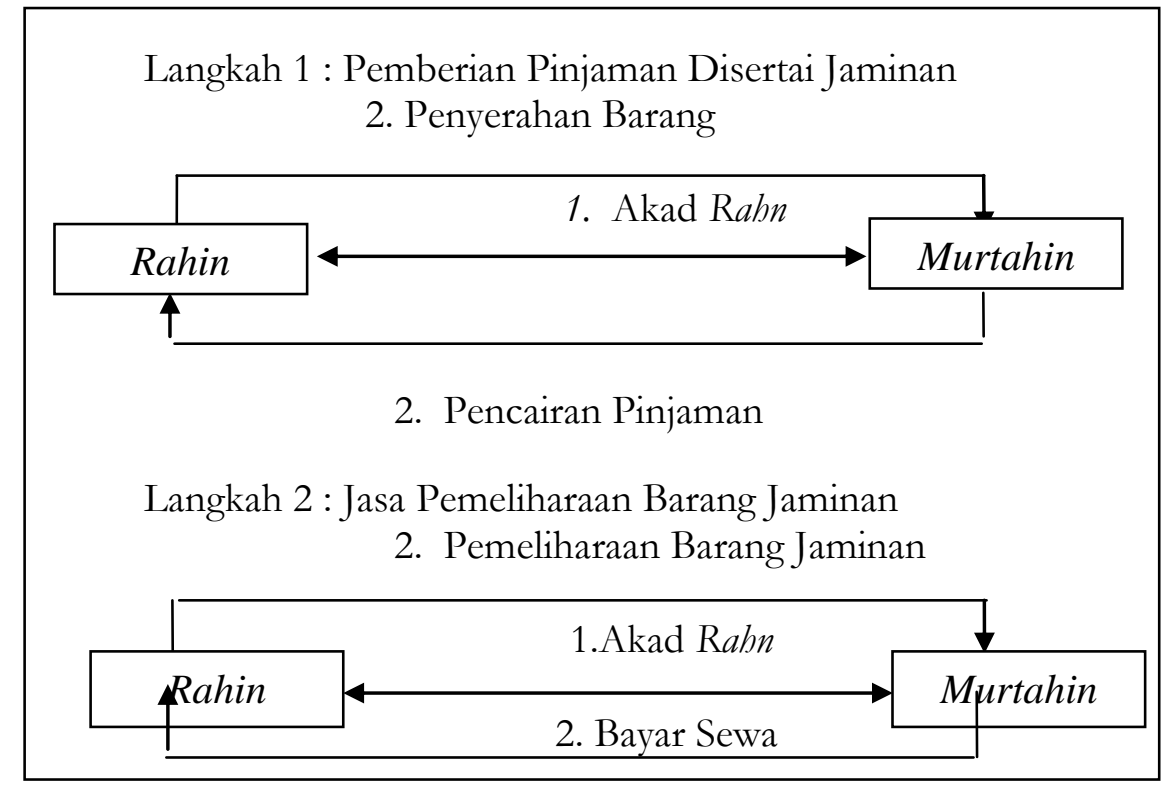

Rukun akad transaksi, meliputi: a) Orang yang berakad, yaitu: Pihak berutang (rabin); Pihak yang berutang (murtabin); b) Sighat (kontrak ijab kabul); c) Harta yang digadaiakan (marbun); d) Pinjaman (marbun bib). Dalam landasan Syariah tersebut, maka mekanisme operasional Pegadaian Syariah dapat digambarkan sebagai berikut; Melalui akad rahn, nasabah menyerahkan barang bergerak dan kemudian pegadaian menyimpan dan merawatnya di tempat yang telah disediakan oleh pegadaian. Menurut pandangan dari hasil wawancara dengan Rully Yusuf selaku General Manager SBU Syariah PT Pegadaian (Persero) Jakarta menyatakan sebagai berikut:

"Perkembangan Pegadaian Syariah di Indonesia ini. Dari tahun 2003-2008, awalnya hanya satu prodak. Namanya rahn yang dikenal dengan gadai syariah. Apa itu rahn, rahn adalab transaksi gadai yang jangka waktunya 120 bari untuke sistem manajemennya atau sistem transaksinya, namun secara akad dia berbeda, Adapun akad Gadai Syariah ini menggunakan konsumsi sesuai dengan yang digariskan Fatwah 25/26 tabun 2002. Produk pertama rabn Pegadain Syariah adalah nasabah membawa barang, barangnya itu disimpan di pegadaian murni semuanya disimpan, kalau motor dengan surat-suratnya disimpan di pegadaian, kemudian dinilai oleh penaksir Pegadaian Syariah. Adapun outlate kita terpisah dengan outlite konvensional dan tidak menyatu. Kita mendirikan cabang-cabang yang khusus syariah sesuia dengan tuntutan dan kebutuhan masyarakat. Inilah 
tujuan didirikan Pegadaian Syariah untuk memenubi kebutuhan masyarakat yang ingin bertransaksi gadai secara syariah. ${ }^{19}$ "

Kalau berbicara tentang perkembangan. Menurut peneliti, perkembangan Bisnis Syariah di Indonesia sendiri cukup menjanjikan. Besarnya jumlah penduduk muslim di Indonesia turut menjadi pendorong pertumbuhan bisnis syariah. Misalnya kenaikan aset perbankan syariah telah mencapai angka $30 \%$. Indonesia pun dianggap sebagai motor penggerak pertumbuhan bisnis syariah di dunia bersama negara lainnya seperti Qatar, Turki, dan Malaysia. Bahkan, Indonesia juga dilirik oleh negara lain sebagai pusat pembelajaran pengembangan industri syariah. Hal ini pun berdampak pada pertumbuhan industri keuangan syariah di Indonesia. Bukan hanya bisnis lembaga keuangan syariah yang berkembang, tapi juga industri lainnya seperti kuliner, kosmetik, farmasi, hiburan dan pariwisata berbasis syariah. Hal ini menunjukkan bahwa masih banyak potensi produk-produk syariah di Indonesia yang terbuka luas untuk digali dan dikembangkan. Saat ini Bisnis Syariah tidak hanya dianut oleh kelompok pengusaha kecil dan perorangan. Pengusaha besar dan bahkan lingkup pemerintah mulai melirik Bisnis Syariah. hal ini dapat kita lihat dari banyaknya usaha syariah yang berdiri di bawah bendera naungan mereka.

Dari penjelasan di atas dapat disimpulkan bahwa perkembangan pegadaian syariah sangat signifikan. Sebgaimana kita ketahui produk pertama adalah rahn, dimana Pegadain Syariah adalah nasabah membawa barang, barangnya itu disimpan di pegadaian murni semuanya disimpan, kalau motor dengan surat-suratnya disimpan di pegadaian kemudian dinilai oleh penaksir pegadaian syariah. Pegadaian Syariah akan memperoleh keuntungan hanya dari biaya sewa tempat yang dipungut. Bukan tambahan berupa bunga atau sewa modal yang diperhitungkan dari uang pinjaman. Di sini dapat dikatakan proses pinjam meminjam uang hanya sebagai "lipstick" yang akan menarik minat konsumen untuk menyimpan barangnnya di Pegadaian.

Adapun ketentuan atau persyaratan yang menyertai akad tersebut meliputi: Pertama, akad--akad tidak mengandung syarat fasik/batil seperti murtahin mensyaratkan barang jaminan dapat di manfaatkan tanpa batas. Kedua, Marbun bih (Pinjaman)--Pinjaman merupakan hak yang wajib dikembalikan kepada murtabin dan bisa dilunasi dengan barang yang dirabnkan tersebut. serta, pinjaman itu jelas dan tertentu. Ketiga, Marbun (barang yang dirahnkan). Marbun bisa dijual dan nilainya seimbang dengan pinjaman, memiliki nilai, jelas ukurannya, milik sah penug dari rahn, tidak terkait dengan hak orang lain, dan bisa diserahkan baik materi maupun manfaatnaya. Keempat, Jumlah maksimum dana rahn dan nilai likuidasi barang yang digadaikan serta jangka waktu rahn ditapkan dalam prosedur. Kelima, Rahin dibebani jasa manajemen atas barang berupa biaya asuransi, baiaya penyimpanan, biaya keamanan, dan biaya

19 Wawancara dilakukan pada hari Jum'at tanggal 26 Mei 2017 
pengelolaan serta administrasi. Adapun teknis operasional dalam lemabaga pegadaian syariah dapat dilustrasikan dalam gambar sebagai berikut:

\section{Diagram 2.}

Operasional dalam lemabaga pegadaian syariah

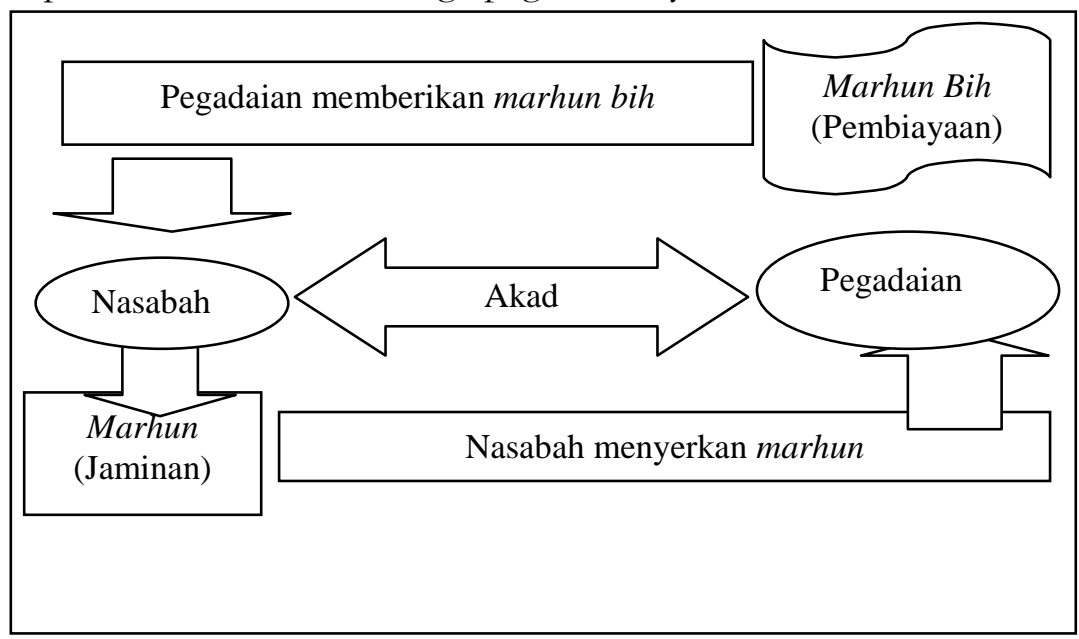

Diagram 2 menginformasikan bahwa Operasional Pegadaian Syariah dapat digambarkan sebagai berikut: Melalui akad rahn, nasabah menyerahkan barang bergerak dan kemudian pegadaian menyimpan dan merawatnya di tempat yang telah disediakan oleh pegadaian. Akibat yang timbul dari proses penyimpanan adalah timbulnya biaya-biaya yang meliputi nilai investasi tempat penyimpanan, biaya perawatan dan keseluruhan proses kegiatan. Atas dasar ini dibenarkan bagi pegadaian mengenakan biaya sewa kepada nasabah sesuai jumlah yang disepakati oleh kedua belah pihak.Pegadaian Syariah akan memperoleh keuntungan hanya dari biaya sewa tempat yang dipungut bukan tambahan berupa bunga atau sewa modal yang diperhitungkan dari uang pinjaman . Sehingga disini dapat dikatakan ;proses pinjam meminjam uang hanya sebagai "lipstick" yang akan menarik minat konsumen untuk menyimpan barangnya di pegadaian.

Untuk dapat memperoleh layanan dari Pegadaian Syariah, masyarakat hanya cukup menyerahkan harta geraknya (emas, berlian, kendaraan, dan lainlain) untuk dititipkan disertai dengan photo copy tanda pengenal. Staf penaksir kemudian akan menentukan nilai taksiran barang bergerak tersebut yang akan dijadikan sebagai patokan perhitungan pengenaan sewa simpanan (jasa simpan) dan plafon uang pinjaman yang dapat diberikan. Taksiran barang ditentukan berdasarkan nilai intrinsik dan harga pasar yang telah ditetapkan oleh PT. Pegadaian (Persero). Maksimum uang pinjaman yang dapat diberikan adalah sebesar $91-95 \%$ dari nilai taksiran barang. Setelah melalui tahapan ini, Pegadaian Syariah dan nasabah melakukan akad dengan kesepakatan: 1) Jangka waktu penyimpanan barang dan ditetapkan selama maksimum empat bulan; 2) 
Nasabah bersedia membayar jasa simpan sebesar Rp 45-80,-- (empat puluh lima sampai delapan puluh rupiah) dari kelipatan taksiran Rp 10.000,- per 10 hari yang dibayar bersamaan pada saat melunasi pinjaman; 3) Membayar biaya administrasi yang besarnaya ditetapakan oleh Pegadaian pada saat pencaiaran uang pinjaman.

Dalam hal ini rabin diberikan kelonggaran, yaitu: 1) Melakukan penebusan barang/pelunasan pinjaman kapan pun sebelum jangka waktu empat bulan, 2) Mengangsur uang pijaman dengan membayar terlebih dahulu jasa simpan yang sudah berjalan titambah bea adaministrasi, 3) Bisa juga dengan hanya membayar jasa simpanannya dengan bea administrasi saja terlebih dahulu jika pada saat jatuh tempo nasabah belum mampu melunasi pinjaman uangnya.

Jika rahin sudah tidak mampu melunasi utang, maka Pegadaian Syariah melakukan eksekusi barang jaminan dengan cara dijual, selisi antara nilai penjualan dengan pokok pinjaman, jasa simpan dan bea lelang merupakan uang kelebihan yang menjadi hak nasabah. Nasabah diberi kesempatan selama satu tahun untuk mengambil uang kelebihan, jika dalam satu tahun ternayata nasbah tidak mengambil uang tersebut, Pegadaian Syariah akan menyerahkan uang kelebiahan kepada Badan Amil Zakat sebagai ZIS. Dari uraian ini dapat dicermati perbedaan yang cukup mendasar dari teknik transaksi Pegadaian Syariah dibandingkan dengan pegadaian konvensional, yaitu: 1) Di pegadaian konvensional, tambahan yang harus dibayar aleh nasabah yang disebut sebagai sewa modal, dihitung dari nilai pinjaman; 2) Pegadaian konvensional hanya melakukan satu akad perjanjian, yaitu utang piutang dengan jaminan barang bergerak yang jika ditinjau dari aspek hukum konvensional, keberdaan barang jaminan dalam gadai bersifat acessoir, sehingga pegadaian konvensional bisa tidak melakukan penahan barang jaminan atau dengan kata lain melakukan praktik fidusial. Berbeda dengan Pegadaian Syariah yang masyarakat secara mutlak keberadaan barang jaminan untuk membenarkan penarikan bea jasa simpan.

\section{Metode Mendapatkan Marbun Bih}

Metode memperoleh pinjaman di Pegadaian Syariah sebagai berikut (lihat Diagram 3):

\section{Diagram 3.}

Metode Mendapatkan Marbub Bih

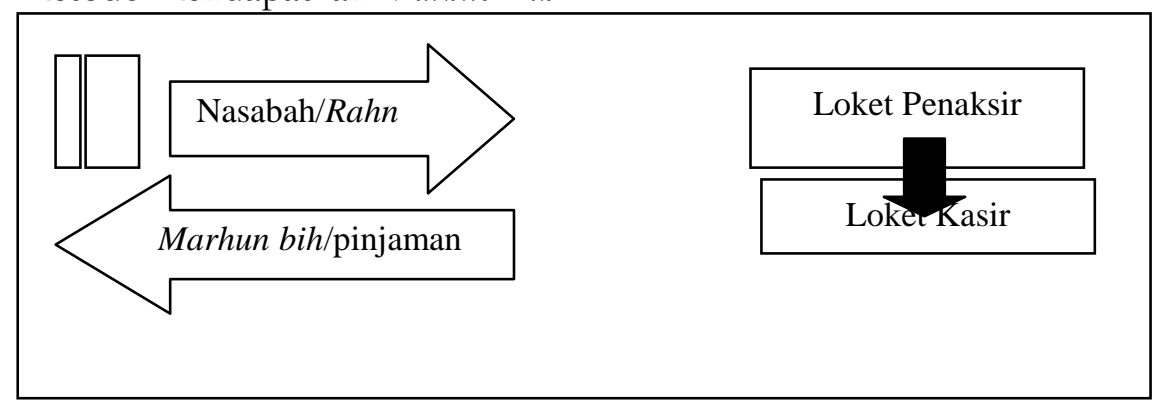


Keterangan: 1) Calon nasabah lansung ke loket penaksir dan menyerahkan marbun untuk ditaksir nilainya; 2) Calon nasbah menandatangani Surat Bukti Rabn (SBR); 3) Calon nasabah datang ke loket Kasir untuk menerima uang pinjaman.

\section{Pengoolongan Marbun Bih}

Besarnya jumlah uang pinjaman yang disalurkan sangat dipengaruhi golongan marbun yang telah ditapakan bedasarkan ketentuan Direksi PT. Pegadaian (Persero). Pinjaman yang diberikan digolongkan berdasarkan tingkat tarif simpanan, bukti bukan sewa modal ataupun jangka waktu pinjaman, menjadi 8 golongan sebagaimana dijelaskan pada tabel yang mana prosentase marbun bih sebesar 95\% dari taksiran. Minimum uang marbun bih per surat bukti rabin (SBR) adalah Rp. 50.000 dengan pembagian plapon uang pinjaman sebagai berikut. Menurut pandangan dari hasil wawancara kepada Dwi Agus Pramudya selaku Direktur IV PT Pegadaian (Persero) Jakarta menyatakan sebagai berikut:

"Biaya ijarah atas biaya sewa tempat yang disediakan oleh pihak PT Pegadaian (Persero) Jakarta yang dikenakan kepada nasabah dibitung kelipatan per 10 hari, 1 hari masuk dalam hitungan 10 bari Untuk biaya ijarahnya berdasarkan dengan nilai taksiran". ${ }^{20}$

Sebagai mana peneliti ketahui. Fatwa DSN No. 92 Tahun 2014, tentang pembiayaan yang disertai rahn memberikan kebolehan (halal) dalam beberapa jenis akad pembiayaan. Adapun akad-akad yang boleh disertai rahn adalah sebagai berikut: 1) Akad utang-piutang (al-dain). 2) Jual beli (al-ba`) yang tidak tunai. 3) Sewa-menyewa (ijarah) yang pembayaran ujrahnya tidak tunai. 4) Musyarakah (perkongsian). 5) Mudharabah. 6) Akad amanah (untuk menghindari penyelewengan perilaku). Karena itu rumus dan tarif Ijarah bisa kita lihat bisa kita lihat di tabel dan beberapa simulasi (lihat tabel 1), dengan mengunakan rumus sebagai:

Taksiran/Rp 10.000 x Tarif Marbin Bih x Jangka waktu/10

Tabel 1.

Pembagian Plapon Uang Pinjaman/Tarip Ijarah

\begin{tabular}{|c|r|r|r|c|c|c|c|c|c|}
\hline \multirow{2}{*}{ Gol } & \multicolumn{2}{|c|}{ Marhun Bih } & \multirow{2}{*}{$\begin{array}{c}\text { Tarif } \\
\text { Admn }\end{array}$} & \multicolumn{3}{|c|}{ Tarif Ijaroh } & \multicolumn{3}{c|}{$\%$ Marhun Bih pada Taksiran } \\
\cline { 5 - 10 } & & & & Emas & Elek & Kend & Emas & Elektronik & Kendaraan \\
\hline A & 50.000 & 500.000 & 1.000 & 45 & 45 & 45 & $95 \%$ & $95 \%$ & $95 \%$ \\
\hline B1 & 550.000 & 1.00 .000 & 3.000 & 73 & 75 & 78 & $92 \%$ & $92 \%$ & $92 \%$ \\
\hline B2 & 1.050 .000 & 2.500 .000 & 8.000 & 79 & 80 & 82 & $92 \%$ & $92 \%$ & $92 \%$ \\
\hline B3 & 2.550 .000 & 5.000 .000 & 15.000 & 79 & 80 & 82 & $92 \%$ & $92 \%$ & $92 \%$ \\
\hline
\end{tabular}

${ }^{20}$ Wawancara dilakukan pada hari Senin tanggal 26 Juni 2017 


\begin{tabular}{|c|r|c|r|r|r|r|r|r|r|}
\hline C1 & 5.100 .000 & 10.000 .000 & 25.000 & 79 & 80 & 82 & $92 \%$ & $92 \%$ & $92 \%$ \\
\hline C2 & 10.100 .000 & 15.000 .000 & 40.000 & 79 & 80 & 72 & $92 \%$ & $92 \%$ & $92 \%$ \\
\hline C3 & 15.100 .000 & 20.000 .000 & 60.000 & 62 & 65 & 70 & $92 \%$ & $92 \%$ & $92 \%$ \\
\hline D & 20.100 .000 & keatas & 100.000 & 62 & 65 & 70 & $93 \%$ & $93 \%$ & $93 \%$ \\
\hline
\end{tabular}

Sumber : Surat Edaran (SE) No.22/BS.1.00/2012, tanggal 30 Maret 2012

Simulasi : Nasabah menggadaikan barang emas berupa kalung 23 karat dengan berat 17 gram diketahui nilai taksirnya Rp 9.579.500. Maka uang pinjaman maksimum yang diperoleh nasabah adalah:

\section{Nilai taksiran $\times$ Persentase uang pinjaman/marhun bib}

$$
9.579 .500 \times 92 \%=8.813 .140
$$

Jadi, nilai maksimum uang pinjaman/marbun bih yang diperoleh nasabah senilai Rp 8.813.140.

\section{Besarnya Tarif}

Pertama, Tarif Biaya Administrasi (qordul hasan): Biaya adaministrasi murah dan tidak memberatkan atas transaksi marbun bib ditetapkan sebesar Rp. 50,- untuk setiap kelipatan marbun bih Rp. 5.000, untuk semua golongan marbun bih. Terhadap hasil hitungan biaya administrasi ini dilakukan pembulatan ke Rp. 100 terdekat. Rp. 1 s/d Rp. 50 dianggap sama dengan 0 (nol); diatas Rp. 50 s/d Rp. 100 dibulatkan ke Rp. 100. biaya administrasi dikenakan hanya sekali pada saat akad.

Kedua, Tarif Jasa Simpanan (Ijarah): Tarif jasa simpanan dibedakan antara tarif jasa simpanan kantong dengan tarif jasa simpanan gudang.

Tabel 2.

Tarif Diskon Ijarah

\begin{tabular}{|c|c|c|}
\hline \multicolumn{2}{|c|}{ Besaran Marhun Bih } & Tarif Diskon \\
\hline$>=85 \%$ & $\mathrm{X}$ taks & $0 \%$ \\
\hline $80 \%-84 \%$ & $\mathrm{X}$ taks & $7 \%$ \\
\hline $75 \%-79 \%$ & $\mathrm{X}$ taks & $14 \%$ \\
\hline $70 \%-74 \%$ & $\mathrm{X}$ taks & $20 \%$ \\
\hline $65 \%-69 \%$ & $\mathrm{X}$ taks & $26 \%$ \\
\hline $60 \%-64 \%$ & $\mathrm{X}$ taks & $32 \%$ \\
\hline $55 \%-59 \%$ & $\mathrm{X}$ taks & $38 \%$ \\
\hline $50 \%-54 \%$ & $\mathrm{X}$ taks & $44 \%$ \\
\hline $45 \%-49 \%$ & $\mathrm{X}$ taks & $50 \%$ \\
\hline $40 \%-44 \%$ & $\mathrm{X}$ taks & $56 \%$ \\
\hline $35 \%-39 \%$ & $\mathrm{X}$ taks & $61 \%$ \\
\hline $30 \%-34 \%$ & $\mathrm{X}$ taks & $66 \%$ \\
\hline $25 \%-29 \%$ & $\mathrm{X}$ taks & $71 \%$ \\
\hline $20 \%-24 \%$ & $\mathrm{X}$ taks & $76 \%$ \\
\hline $15 \%-19 \%$ & $\mathrm{X}$ taks & $81 \%$ \\
\hline$<=14 \%$ & $\mathrm{X}$ taks & $85 \%$ \\
\hline
\end{tabular}

Sumber : Surat Edaran (SE) No.22/BS.1.00/2012, tanggal 30 Maret 2012

Simulasi: Nasabah menggadaiakan barang perhiasan berupa gelang emas 22 karat dengan berat 12 gram, setelah dihitung ternyata nilai taksiran tersebut 
senilai $\mathrm{Rp} 6.468 .000$ dan nilai pinjaman maksimum senilai Rp 5.950.560 dengan melakukan pinjaman di bawah maksimum senilai Rp 4.000.000 dalam jangka waktu selama10 hari, maka biaya ijarah dan biaya administrasi adalah sebagai berikut:

\section{Tabel 3.}

Biaya dan Diskon Ijarah

\begin{tabular}{|c|c|}
\hline Biaya Ijarah & $\begin{array}{l}\text { : Taksiran/Rp } 10.000 \times \text { Tarif Marbun Bib } \times \text { Jangka waktu/10 } \\
: \text { : } 6.468 .000 / \text { Rp } 10.000 \times 71 \times 10 \text { hari/10 } \\
: \text { Rp } 45.922 \text { (dibulatkan } \operatorname{Rp} 46.000 \text { ) }\end{array}$ \\
\hline \multirow[b]{2}{*}{ Diskon Ijarah } & $\begin{array}{l}\text { Persentase pinjaman } \\
: \text { Pinjaman/taksiran x } 100 \\
: 4.000 .000 / 6.468 .000 \times 100 \\
: 61 \%\end{array}$ \\
\hline & $\begin{array}{l}\text { Diskon Ijarah } \\
\text { : Ijarah asal - (ijarah asal x persentase Diskon Ijarab) } \\
: 46.000-(46.000 \times 32 \%) \text { Pinjaman Rp } 4.000 .000 \text { adalah } \\
61 \% \text { dari harga taksiran barang. Pinjaman } 60-64 \% \text { dari } \\
\text { nilai taksiran mendapat diskon sebesar 32\%) } \\
: 46.000-11.960 \\
: 34.040 \text { (dibulatkan } 34.100)\end{array}$ \\
\hline \multicolumn{2}{|c|}{$\begin{array}{l}\text { Jadi, uang yang harus dibayar oleh nasabah untuk melunasi pinjamannya selama } 10 \\
\text { hari Rp 4.034.100 (pinjaman awal ditambah biayah ijarab). }\end{array}$} \\
\hline $\begin{array}{l}\text { Biaya } \\
\text { Administrasi }\end{array}$ & $\begin{array}{l}\text { Biaya administrasi yang dikenakan kepada nasabah saat } \\
\text { melakukan akad disepakati senilai Rp } 25.000 \text { (Golongan B3) }\end{array}$ \\
\hline
\end{tabular}

Dari simulasi yang ditampilkan pada Tabel 3, dapat diuraikan sebagai berikut: Pertama, Apabilah nasabah melakukan pinjman maksimum senilai Rp 5.590.560 dari taksiran Rp 6.468.000 dalam jangka waktu 10 hari, maka nasabah dikenakan biaya ijarah senilai Rp. 46.000. Kedua, Apabila nasabah melakukan pinjaman di bawah maksimum senilai Rp. 4.000 .000 dari pinjaman ,aksimum senilai Rp 5.950.560 dari taksiran senilai 6.468 .000 dalam jangka waktu 10 hari, maka nasabah dikenakan biaya ijarah senilai Rp 34.100,- Ketiga, Marbun Kantong (emas/berlian): Marbun jenis perhiasan yang ditebus tarif jasa simpan sebesar Rp. 45-79,. Per 10 hari masa penyimpanan untuk setiap kelipatan taksiran marbun emas sebesar Rp. 10.000, satu hari masa penyimpanan duhitung sama dengan 10 hari. Terhadap hasil hitungan jasa simpanan ini di lakukan pembulatan Rp. 100,. terdekat; Rp. 1 s/d Rp. 50 dianggap sama dengan 0 (nol); di atas Rp. 50 s/d Rp.100 dibulatkan ke Rp. 100,. Keempat, Marbun gudang: Marbun jenis elektronik, alat rumah tangga lainnya yang ditebus dikenakan tarif jasa simpanan sebesar Rp. 45-80 per 10 hari masa penyimpanan untuk setiap 
kelipatan taksiran marhun emas sebesar Rp. 10.000. sedangkan marbun jenis kendaraan bermotor (mobil dan motor) yang ditebus, digunakan tarif jasa simpanan sebesar Rp. 45-82 per 10 hari masa penyimpanan untuk setiap kelipatan taksiran marbun emas sebesar Rp. 10,000,. Satu hari masa penyimpanan dihitung sama dengan 10 hari. Terhadap hasil hitungan jasa simpanan ini dilakukan pembulatan Rp.100 terdekat; Rp.1 s/d Rp. 50,. dianggap sama dengan o (nol); di atas Rp. 50 s/d Rp. 100,. Dibulatkan ke Rp. 100, Selanjutnya, lihat tabel 4 berikut ini:

\section{Tabel 4.}

Tarif Jasa Simpanan Marhun Gudang di Prgadaian Syariah

\begin{tabular}{|l|l|}
\hline \multicolumn{1}{|c|}{ Jenis Marhun Gudang } & \multicolumn{1}{c|}{ Pembulatan } \\
\hline - Emas dan berlian & $\begin{array}{l}\text { - Taksiran / Rp. 10.000 x Rp. 45-79 x Jangka } \\
\text { waktu/10 }\end{array}$ \\
- Elektronik, mesin jahit, sepeda dan \\
$\begin{array}{l}\text { barang rumah tangga lainnya } \\
\text { Taksiran / Rp. 10.000 x Rp. 45-80 x Jangka } \\
\text { waktu / } 10\end{array}$ \\
$\begin{array}{l}\text { Kendaraan bermotor (motor dan } \\
\text { mobil) }\end{array}$ & $\begin{array}{l}\text { Taksiran / Rp. 10.000 x Rp. 45-82 x Jangka } \\
\text { waktu / 10 }\end{array}$ \\
\hline
\end{tabular}

Sumber : Surat Edaran (SE) No.22/BS.1.00/2012, tanggal 30 Maret 2012

\section{Tabel 5.}

Tarif Biaya Administrasi dan Surat Hilang di Pegadaian Syariah

\begin{tabular}{|c|c|c|}
\hline Golongan & Biaya Administrasi & Biaya Surat Hilang \\
\hline A & 1.000 & 1.000 \\
B & 3.000 & 2.000 \\
C1 & 8.000 & 3.000 \\
C2 & 15.000 & 4.000 \\
C3 & 25.000 & 5.000 \\
C4 & 40.000 & 6.000 \\
D1 & 60.000 & 6.000 \\
D2 & 100.000 & 6.000 \\
\hline
\end{tabular}

Sumber : Surat Edaran (SE) No.22/BS.1.00/2012, tanggal 30 Maret 2012

\section{Sistem Cicilan dan Perpanjangan}

Rahn dapat memilih cara pelunasan sekaligus atau dengan cara cicilan, sehingga memudahkan dan tidak memberatkan. Jika masa 4 bulan habis dan rabin belum dapat melunasi, maka dengan mangajukan permohonan, serta menyelesaikan biayanya, maka jangka waktu pinjaman dapat diperpanjang 4 bulan lagi.

Pelunasan Marbun Bib dan pengambilan Marbun

Adapun cara pelunasan marbun bib dan pengambilan barang jaminan di Pegadaian Syariah adalah sebagai berikut: Pertama, setiap saat uang pinjaman dapat dilunasi tanpa harus menunggu habisnya jangka waktu akad; Kedua, proses pengambilan pinjaman sampai penerimaan kembali barang jaminan tidak dikenakan biaya apa pun, kecuali membayar jasa simpanan sesuai tarif. 
Proses Pelelangan Marbun

Adapun proses pelelangan barang jaminan adalah: a) Satu minggu sebelum pelelangan, diberitahukan kepada nasabah yang barangnya akan dilelang; b) Ditetapkan harga emas pegadaian pada saat pelanggan, dengan bea lelang pembeli, $1 \%$ penjual dan 1\% bea lelang; c) Hasil pelelangan setelah dikurangi, kewajiban nasabah, dan sisanya dikembalikan ke nasabah; b) Sisa kelebihan yang tidak diambil selama 1 tahun, dikembalikan kepada Baitul Maal yang terakreditasi.

\section{Pegadaian Syariah pada PT. Pegadaian (Persero) Jakarta: Praktek dan Perspektif Hukumnya}

\section{Kebutuban Transaksi Gadai Sesuai Syariab}

Menurut pandangan dari hasil wawancara kepada Dwi Agus Pramudya selaku Direktur IV PT Pegadaian (Persero) Jakarta menyatakan sebagai berikut:

"Pegadaian Syariah dalam perspektif Perum Pegadaian, hadir untuk menjawab kebutuhan transaksi gadai sesuai Syariah. Untuk solusi pendanaan yang cepat, praktis, dan menentramkan. Oleh karena hanya dalam waktu 15 menit, kebutuban masyarakat yang memerlukan dana akan terpenubi, tanpa memerlukan membuka rekening ataupun prosedur lain yang memberatkan. Customer Perum Pengadaian cukup membawa barang-barang berharga miliknya, dan saat itu juga akan mendapatkan dana yang dibutubkan dengan jangka waktu hingga 120 hari dan dapat dilunasi sewaktu-waktu. Jika masa jatub tempo tiba dan nasabah masih memerlukan dana pinjaman tersebut, maka pinjaman tersebut dapat diperpanjang hanya dengan membayar sewa simpan dan pemeliharaan serta biaya administrasi.

Pemberian Gadai Syariah, dapat menentramkan dalam pengertian sumber dana. Perum Pegadaian berasal dari sumber yang sesuai dengan Syariah. Proses gadai berlandaskan prinsip Syariah, serta didukung oleh petugas-petugas dan outlet dengan nuansa Islami sehingga lebih syar'i dan menentramkan",21

Dari penjelasan di atas. Peneliti dapat menyimpulkan, bahwa Pegadaian Syariah dalam perspektif perum. Pegadaian hadir untuk menjawab kebutuhan transaksi gadai sesuai Syariah menentramkan, karena sumber dana yang dimiliki oleh pegadaian syariah didapat dari sumber dana yang halal dan sesuai dengan prinsip syariah. Produk dan layanan pencairan kredit pada kantor pegadaian syariah pada umumnya hanya menggunakan produk layanan rahn dan ijarah saja. Padahal, sebuah lembaga pegadaian idealnya tidak hanya melayani dua model jasa.

Menurut peneliti, Pegadaian syariah PT. Pegadaian (Persero) hadir untuk menjawab kebutuhan transaksi gadai sesuai syariah. Untuk solusi pendanaan yang cepat, praktis, aman, dan menentramkan, karena hanya dalam waktu 15 menit kebutuhan masyarakat yang memerlukan dana akan terpenuhi

\footnotetext{
${ }^{21}$ Wawancara dilakukan pada hari Senin tanggal 26 Juni 2017
} 
tanpa melakukan pembukaan rekening ataupun prosedur lain yang memberatkan dan terkesan sangat rumit. Nasabah pegadaian syariah PT. Pengadaian (Persero) cukup membawa barang-barang berharga miliknya yang akan di gadaikan, maka pada saat itu juga akan mendapatkan dana yang dibutuhkan dengan jangka waktu hingga 120 hari dan dapat dilunasi sewaktuwaktu. Jika masa jatuh tempo tiba dan nasabah masih membutuhkan dana pinjaman tersebut, maka pinjamannya dapat diperpanjang hanya dengan membayar sewa simpan dan pemeliharaan serta biaya administrasi.

\section{Konsep Dasar Lembaga Gadai Syariah}

Dalam Al-Quran Surat Al-Baqarah ayat 283 Allah berfirman:

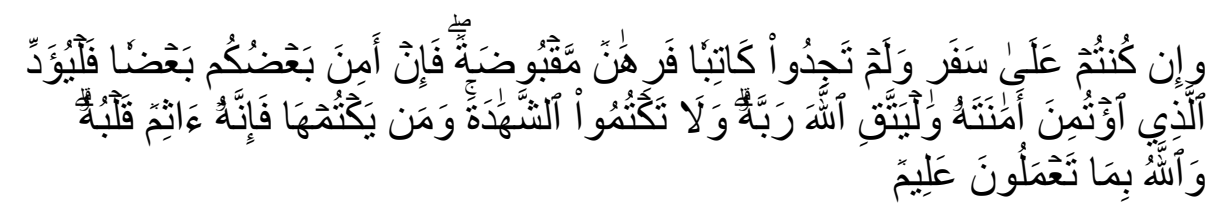

Artinya: "Jika kamu dalam perjalanan (dan bermu'amalah tidak secara tunai), sedang kamu tidak memperoleh seorang penulis, maka hendaklah ada barang tanggungan yang dipegang (oleh yang berpiutang). Akan tetapi jika sebagian kamu mempercayai sebagian yang lain, maka hendaklah yang dipercayai itu menunaikan amanatnya (butangnya) dan hendaklah ia bertakwa kepada Allah Tubannya; dan janganlah kamu (para saksi) menyembunyikan persaksian. Dan barangsiapa yang menyembunyikannya, maka sesunggubnya ia adalab orang yang berdosa batinya; dan Allah Maha Mengetahui apa yang kamu kerjakan"

Ayat ini menjelaskan, bahwa pada hakikatnya rahn merupakan salah satu bentuk dari konsep muamalah, dengan mengedepankan sikap menolong dan amanah. Begitu juga dalam hadits Rasulullah Saw dari Ummul Mukminin, Aisyah r.a yang diriwayatkan oleh Abu hurairah, di sana nampak sikap menolong antara Rasulullah dengan orang Yahudi saat Rasulullah Saw menggadaikan baju besinya kepada orang Yahudi tersebut.

Pada dasarnya, hakikat dan fungsi lembaga gadai dalam Islam adalah semata-mata untuk memberikan pertolongan kepada orang yang membutuhkan dengan bentuk marhun sebagai jaminan, dan bukan untuk kepentingan komersial dengan mengambil keuntungan yang sebesar-besarnya tanpa mengiraukan kemampuan orang lain. Dalam realita kehidupan, terkadang kita sangat membutuhkan uang untuk menutupi kebutuhan mendesak maka bila tidak ada orang yang bisa memberikan pinjaman dan kita memiliki barang yang layak digadaikan, ke lembaga gadai syariah kita dapat menjadikan barang tersebut jaminan gadai atas utangnya. Demikianlah, Allah mensyariatkan rabn (gadai) untuk kemaslahatan orang yang menggadaikan (rabin), pemberi utang (murtabin) dan masyarakat. 
Untuk yang menggadaikan (rabin), ia mendapatkan keuntungan yaitu dapat menutupi kebutuhannya sehinnga bisa menyelamatkan diri dari krisis yang menimpanya, dan menghilangkan kegunduhan di hatinya. Bahkan, kadang ia bisa berdagang dengan modal utang tersebut, lalu menjadi sebab ia menjadi kaya. Adapun pihak pemberi utang (murtabin), ia menjadi tenang dan merasa aman atas haknya dan mendapatkan keuntungan syar'i, dan bila berniat baik, otomatis ia mendapatkan pahala dari Allah Swt. Kemaslahatan yang kembali kepada masyarakat, yaitu memperluas interaksi perdagangan dan saling memberikan kecintaan dan kasih sayang di antara manusia, karena peminjaman dengan rahn ini termasuk katagori tolong-menolong dalam kebaikan dan takwa. Disana terdapat manfaat yang menjadi solusi dalam krisis, memperkecil permusuhan.

\section{Menghilangkan Unsur Bunga dan Riba dalam Transaksi Gadai Syariah}

Mencermati proses operasional Pegadaian Syariah di kantor pusat PT Pegadaian (Persero) Jakarta sebagaimana diuraikan di atas, mulai dari mobilisasi dana untuk modal dasar sampai kepada penyalurannya kepada masyarakat, seluruhnya tidak boleh mengandung unsur riba, sebab dalam operasionalnya Pegadaian Syariah PT Pegadaian (Persero) Jakarta tidak mengenakan bunga kepada nasabah, tetapi hanya mengenakan margin/keuntungan berdasarkan kesepakatan kedua belah pihak dan biaya gadai kepada nasabah. Tentang ribanya bunga sebenarnya telah ditetapkan dalam suatu pertemuan penelitian Islam yang dihadiri 150 para ulama terkemuka dalam konferensinya yang kedua pada bulan Muharram 1385 H atau Mei 1965 di Kairo, Mesir.

Di Setelah itu berbagai forum ulama internasional yang juga mengeluarkan fatwa pengharaman bunga bank, yaitu: 1) Majma' al-Fiqh al-Islamy Negara-negara OKI yang diselenggarakan di Jeddah tanggal 10 - 16 Rabi'ul Awal 1406 H atau 22 - 28 Desember 1985; 2) Majma' al-Figh Rabithah al-'Alam al-Islamy, Keputusan 6 Sidang IX yang diselenggarakan di Mekkah tanggal 12 19 Rajab 1406 H; 3) Keputusan Dar It-Itfa, Kerajaan Saudi Arabia, 1979; 4) Keputusan Supreme Shariah Court, Pakistan 22 Desember 1999. Di Indonesia, fatwa ulama' tentang bank dan bunga bank ditetapkan dalam Sidang Lajnah Tarjih Muhammadiyah tahun 1968 di Sidoarjo yang menyarankan kepada PP Muhammadiyah untuk mengusahakan terwujudnya konsepsi sistem perekonomian khususnya lembaga perbankan yang sesuai dengan kaidah Islam. Setelah itu dalam Munas Alim Ulama dan Kongres NU tahun 1992 di Bandar Lampung yang mengamanatkan berdirinya Bank Islam dengan sistem tanpa bunga.

Majelis Ulama Indonesia (MUI) pada tanggal 10 Februari 1999 membentuk sebuah dewan yang disebut Dewan Syari'ah Nasional (DSN) yang telah mengeluarkan lebih dari 40 fatwa yang menyangkut berbagai jenis kegiatan keuangan, produk, dan jasa keuangan syariah. Fatwa DSN pertama yang dikeluarkan adalah No. 01/DSN-MUI/IV/2000 tentang Giro tanggal 26 
Dzulhijjah $1420 \mathrm{H}$ atau 1 April $2000 \mathrm{M}$, yang memutuskan bahwa giro yang tidak dibenarkan secara syari'ah yaitu giro yang berdasarkan perhitungan bunga, kemudian No. 02/DSN-MUI/IV/2000 tentang Tabungan tanggal 26 Dzulhijjah $1420 \mathrm{H}$ atau 1 April $2000 \mathrm{M}$, yang memutuskan bahwa tabungan yang tidak dibenarkan secara syari'ah yaitu tabungan yang berdasarkan perhitungan bunga, dan No. 03/DSNMUI/IV/2000 tentang Deposito tanggal 26 Dzulhijjah $1420 \mathrm{H}$ atau 1 April $2000 \mathrm{M}$, yang memutuskan bahwa deposito yang tidak dibenarkan secara syari'ah yaitu deposito yang berdasarkan perhitungan bunga, namun ketiga fatwa tersebut belum mengundang reaksi dari masyarakat.

Bunga (interest/ fa-idah) adalah tambahan yang dikenakan untuk transaksi pinjaman uang (al-qard) yang diperhitungkan dari pokok pinjaman tanpa mempertimbangkan pemanfaatan/ hasil pokok tersebut berdasarkan tempo waktu dan diperhitungkan secara pasti di muka berdasarkan persentase. Riba adalah tambahan (ziyadab) tanpa imbalan yang terjadi karena penangguhan dalam pembayaran yang diperjanjikan sebelumnya. Dan inilah yang disebut riba nasi'ah. Praktek pembungaan uang saat ini telah memenuhi kriteria riba yang terjadi pada zaman Rasulullah SAW, yakni riba nasi'ah. Dengan demikian, praktek pembungaan uang ini termasuk salah satu bentuk riba, dan haram hukumnya. Praktek pembungaan uang ini banyak dilakukan oleh bank, asuransi, pasar modal, pegadaian, koperasi, dan lembaga keuangan lainnya termasuk juga oleh individu. Bermuamalah dengan Lembaga Keuangan Konvensional Untuk wilayah yang sudah ada kantor atau jaringan Lembaga Keuangan Syari'ah, tidak diperbolehkan melakukan transaksi yang didasarkan pada perhitungan bunga. Untuk wilayah yang belum ada kantor atau jaringan Lembaga Keuangan Syari'ah, diperbolehkan melakukan transaksi di lembaga keuangan konvensional berdasarkan pada prinsip dharurat/ hajat. Perbedaan utama antara bunga gadai dengan biaya gadai adalah sifat bunga bisa berakumulasi dan berlipat ganda sementara biaya gadai hanya sekali dan ditetapkan di muka. Oleh karena sudah jelas bahwa Pembiayaan yang disertai dengan rabn di Pegadaian Syariah PT Pegadaian (Persero) Jakarta bebas dari riba yang hukumnya dilarang dalam Hukum Islam.

\section{SIMPULAN}

Berdasarkan hasil penelitian dan pembahasan sebagaimana telah diuraikan di atas, penulis menarik sebagai kesimpulan penelitian ini sebagai berikut: Pertama, Pelaksanaan Fatwa 92/2014 "pembiayaan yang disertai dengan rahn" pada pegadaian syariah dengan sistem syariah di kantor pusat PT Pegadaian (Persero) Jakarta telah sesuai dengan Hukum Islam karena alasan sebagai berikut : a) Mayoritas nasabah memilih pembiayaan MULIA dengan alasan mengikuti syariat Islam yaitu karena prinsip bebas bunga, tidak mengandung gharar dan mudah persyaratannya; b) Pelaksanaan Fatwa 92/2014 "pembiayaan yang disertai dengan rahn dalam pembiayaan MULIA telah sesuai 
syarat dan rukunnya menurut hukum Islam, baik yang menyangkut al'akid (para pihak), al-ma'kud 'alaib (obyek perjanjian) maupun sighat (ijab dan kabul).

Kedua, Upaya yang telah dilakukan oleh Pegadaian Syariah kantor pusat PT Pegadaian (Persero) Jakarta, sehingga Pelaksanaan Fatwa 92/2014 "pembiayaan yang disertai dengan rabn tersebut telah sesuai dengan kaidahkaidah Hukum Islam: a) Persyaratan dan prosedur pemberian pinjaman atau pembiayaan telah ditentukan oleh pegadaian syariah kantor pusat PT Pegadaian (Persero) Jakarta. Berdasarkan kaidah-kaidah Hukum Islam: persyaratan sederhana, prosedur mudah, akad secara tertulis, pembiayaan/hutang dengan jaminan barang yang sudah dibeli, tidak dipungut bunga, keuntungan/margin dan isi perjanjian ditentukan oleh kedua belah pihak serta pembiayaan tidak mengandung gharar. b) Pegadaian Syariah kantor pusat PT Pegadaian (Persero) Jakarta, melakukan analisis pembiyaan secara obyektif yang meliputi aspekaspek : karakter (character), kemampuan (capacity), kondisi (condition), agunan (collateral/rahn) dan kepercayaan. c) Untuk memberikan keputusan dikabulkan atau ditolaknya permohonan pembiayaan, didasarkan pada suatu kriteria dan analisis tertentu yang sifatnya obyektif sesuai dengan kejujuran dan keadilan serta dapat dipertanggungjawabkan kepada Sang Pencipta. Hal ini menunjukkan penerapan prinsip kejujuran, keadilan dan prinsip tauhid dalam ekonomi syari'ah

Ketiga, Hambatan pelaksanaan Fatwa 92/2014 "pembiayaan yang disertai dengan rahn pada Pegadaian Syariah kantor pusat PT Pegadaian (Persero) Jakarta adalah faktor-faktor sebagai berikut :a) Pegadaian Syariah relatif baru sebagai suatu sistem keuangan. Oleh karena itu, menjadi tantangan tersendiri bagi Pegadaian Syariah untuk mensosialisasikan syariahnya. dalam berhubungan dengan rahn. b) Kebijakan pemerintah tentang gadai syariah belum sepenuhnya akomodatif terhadap keberadaan Pegadaian Syariah. Di samping itu, keberadaan pegadaian konvensional di bawah kementerian BUMN mempersulit posisi Pegadaian Syariah, bila berinisiatif untuk independen dari pemerintah pada saat pendiriannya. c) Pegadaian kurang populer. Image yang selama ini muncul adalah, bahwa orang yang berhubungan dengan pegadaian adalah mereka yang meminjam dana jaminan suatu barang, sehingga terkesan miskin atau tidak mampu secara ekonomi. d) Kurangnya tenaga profesional yang handal dan mengerti. Bagaimana operasionalisasi Pegadaian Syariah seharusnya, dan sekaligus memahami aturan Islam mengenai Pegadaian. e) Sulitnya memahami kepada masyarakat mengenai bahaya bunga yang sudah mengakar dan menguntungkan bagi segelintir orang. dan pembinaan Pegadaian Syariah. d) Sebagaian masyarakat masih beranggapan bahwa keberadaan Pegadaian Syariah hanya diperuntukan bagi umat Islam. e) Belum banyak masyarakat yang mengetahui keberadaan Pegadaian Syaraiah.] 


\section{Referensi:}

Al-Qur'an al-Karim \& Al-Hadits as-Syarif

Abidin Ibnu'. Radd al-Mubtar 'ala ad-Durr al-Mukhtar. Beirut: Dar al-Fikr, Jilid V, hal. 339

Antonio, Muhammad Syafi'I, Bank Syariah dari Teori ke Praktek, Jakarta: Gema Insani, 2001

Anshari Abdul Ghofur, Gadai syariah di Indonesia : konsep, Implementasi dan Institusionalisasi, Yogyakarta: Gadjah Mada University Press, 2006

Arifin Zainal, Memahami Bank Syariah, Alvabet, Jakarta, 2000

Asy-Syarbaini al Khatib. Mugni al-Mubtaj. Beirut: Dar al-Fikr, 1978

Bukhori Imam, Shobih Bukhori, kitab bad'i $i$ al-wahyi, Kairo:Daarus Syu'ab, juz.3, no. 2278, h.122

Dardir. Asy-Syarh ash-shagir bi Syarh ash-Shawi. Mesir: Dar al-Ma'arif, Jilid III, hal. 303

Dewan Syariah Nasional (DSN). Himpunan fatwa Dewan Syariah Nasional. Jakarta, 2014

Habiburrahman, Rahmawati Yulia, Suhardjo, Budiyana, dan Wartono. Mengenal Pegadaian Syariah. Jakarta : Kuwais, 2016

Haroen, Nasrun. Figh Muamalah. Tangerang: Gaya Media Pratama, Cetakan 2 2007.

Huda Nurul, “Daya Serap Lulusan Program Studi Ekonomi Kenangan Islam”, jurnal Fakultas Ekonomi I, Volume 12, Nomor 1, Jakrta Universitas YARSI Jakarta, 2016) 136-137

Kumar, "Jenis-jenis Penelitian" (Research Methodology: Step by step guide for beginners (2nd.). London: SAGE Publication Ltd. 2005

Sjahdeni Sutan Remi , Perbankan Islam dan Kedudukannya dalam Tata Hukum Perbankan Indonesia, Jakarta: Pustaka Utama Graffiti, 2005

Sobirin, Ahmad, Jurnal: "Meraih Keunggulan Melalui Pengintegrasian Sumber Daya Manuasia dan Perencanaan Strategik", Edisi Khisus Jurnal Siasat Bisnis on Human Reseurces, 2005

Tarmizi, Erwandi. Gadai Emas Syariah, Kamuflase Riba. Pengusaha Muslim. Hal 44-47, 2014

Tim Kashiko, Kamus Lengkap Arab Indonesia, Surabaya: Kashiko, 2000

Wiroso, Jual Beli Murabahah, Ctk.Pedrtama, UII Press, Yogyakarta, 2005 